\title{
Violent Offences, Mental Disorder and Substance-use Disorders
}

\author{
Enric Vicens ${ }^{1}$, Rosa Dueñas ${ }^{2, *}$, Vicenç Tort ${ }^{1,3}$ \\ ${ }^{1}$ Parc Sanitari Sant Joan de Deu, C/ Pujadas 42, Sant Boi de Llobregat, Barcelona, Spain \\ ${ }^{2}$ Parc Sanitari Sant Joan de Deu, C/Numancia, 9-13, Barcelona, Spain \\ ${ }^{3}$ Parc Sanitari Sant Joan de Deu.C.P. Quatre Camins. Crta Masnou a Granollers Km 13 La Roca del Valles, Barcelona, Spain
}

Copyright (C) 2016 Copyright (C) 2016 by authors, all rights reserved. Authors agree that this article remains permanently open access under the terms of the Creative Commons Attribution License 4.0 international License.

\begin{abstract}
Introduction: The relationship between violent offences, mental disorder and substance-use disorders has been widely analyzed but has produced contradictory results. Studies examining this relationship in prison populations are scarce. Objectives: The aim of the study was to analyze the relationship between violent crime, substance-use disorders and mental disorder. Method: This is a descriptive, cross-sectional, epidemiological study of 707 male prisoners. Socio-demographic, clinical and penal data were collected by trained interviewers. Penal data were confirmed using penitentiary records. The clinical version of the Structured Clinical Interview (SCID 1) for DSM-IV Axis I Disorders was used for diagnosis of Axis I mental disorders (including substance-use disorders). Inmates who have lifetime substance-use disorders were classified by type and number of substances used. We considered violent offences: homicide and attempted homicide, aggravated assault, common assault, robbery, threatening behavior, harassment, arson and any sexual offence. Results: Violent offences in inmates who used drugs $(n=370)$ were more prevalent than in inmates who did not $(84.6 \%$ vs. $15,3 \%, \mathrm{p}<0.0001)$. The risk of committing a violent crime is double for people using a substance compared to those who do not and those who are not repeat offenders ( $\mathrm{OR}=2.03 \mathrm{CI} 95 \%$ : 1.08-3.78). This risk increases when considering repeat offenders and those who use more than one substance $(\mathrm{OR}=5.35 \mathrm{CI} 95 \%$ : 1.26-10.05). The presence of a mental disorder turns out not to be significant $(\mathrm{OR}=1.38 \mathrm{CI}$ 95\%: 0.98-1.95). Conclusions: In our study, the greatest risk factors for committing a violent offence were being a re-offender and using more than one substance. Mental disorder was not found to be a risk factor for violent offences.
\end{abstract}

Keywords Prison, Mental Health, Substance Use Disorders, Violent Offence

\section{Introduction}

The number of people imprisoned worldwide must be seen as high, even if rates of incarceration vary among countries and continents. Thus, for the year 2013 (1) in Africa the average number of people imprisoned per 100,000 inhabitants was 205, in America it was 202, in Asia 160, in Oceania 151, and in Europe 98. Furthermore, for each continent there was considerable variation among the countries under study. In the last 6 years, the number of prisoners in Spanish prisons has decreased $19 \%$ (2).

Several studies carried out in Europe attest to the significance of drug use among the prison population (3); between a third and a half of inmates are habitual drug users prior to their imprisonment. In the United States, this figure for prior use rises to as high as $70 \%$ in comparison to $11.2 \%$ for the general population (4). Although a prison term may imply a reduction in use or complete withdrawal, many inmates continue to use drugs, or even begin to use them when they go into prison (3).

Goldstein (5) put forward the hypothesis of a relationship between delinquency and drug use. Subsequently, other studies have examined the implication of drug use in the risk of criminal recidivism. They showed that multiple drug use may increase the level of recidivism as much as 3 or 4 times $(6,7)$.

In addition, epidemiological studies in prison populations have demonstrated the high prevalence of mental disorders in these populations, well above levels for the general population (8-10). Of note is the 4-6 times greater chance of suffering a psychotic episode or a serious depression, while for an antisocial personality disorder the chance is as much as ten times greater $(8,9,11)$.

There is no absolute evidence to either confirm or refute the idea that suffering a mental disorder carries with it an increase in violent behavior. While some authors (12-16) advance the notion that serious mental illness (psychosis and mood disorders) may explain violent behavior, others fail to establish a causal relation between suffering a mental disorder and manifesting violent behavior (17). In the literature there is greater consensus regarding the relationship between violent behavior and the use of drugs in association with a mental disorder $(7,13,15,18,19)$. With 
serious mental illnesses such as schizophrenia and bipolar disorder, the use of drugs increases the likelihood of violence (20). In a ten-year cohort of patients who had suffered a first-episode psychosis (21), the incidence of violence was similar to that for the general population. However, habitual drug use increased the likelihood of violent behavior and was revealed to be a greater risk factor than the psychosis itself (21).

\subsection{Objectives}

The main objective of the study was to analyze the relationship among violent crime, drug use, and mental disorders in the Spanish prison population, as well as to uncover the sociodemographic risk factors associated with committing a violent crime.

\section{Methodology}

We used a descriptive, cross - sectional epidemiological study design. The sample was composed of sentenced male prisoners drawn from five prisons which house between 1000 and 1500 men in each of three Spanish regions (Catalonia, Madrid and Aragon). The number of prisoners in these regions represents $28.8 \%$ of all prisoners in Spain (22). Study inclusion criteria were male sex, ages $18-75$ years, having been sentenced to imprisonment, whose were in an imprisonment in general regime. Exclusion criteria were being on remand, being resident on a prison psychiatric wing, being about to be transferred to another prison, imminent release (free within 6 months) and having insufficient knowledge of the Spanish language. Only those inmates who provided signed informed consent were interviewed. The same number of inmates was chosen from each region, and from the list supplied by each center, using a stratified random sampling technique on an index date. Seven hundred and eighty - three men were eligible for the study and were invited to participate; 707 (90.3\%) consented and were interviewed, and 76 refused to participate. Of the 707 participating inmates, 235 were in prison in Madrid, 222 in Catalonia and 250 in Aragon. Clinical interviews were performed by six psychologists with clinical and/or research experience that were chosen for the study. To ensure inter - rater reliability, the interviewers had a 3-day training period in which they received instruction on the study design and in using the assessment instruments. Two interviewers were assigned to each Spanish region. Sociodemographic, clinical and penal data were collected by the interviewers. Penal data were confirmed using penitentiary records. The clinical version of the Structured Clinical Interview for Diagnostic and Statistical Manual of Mental Disorders-Fourth Edition (DSM - IVTR) Axis I Disorders (23) was used for diagnosis of Axis I mental disorders including drug use disorders. To ensure data quality, strict fieldwork control was implemented. This task was undertaken by the project research team who supervised the interviews and verified informed consent. Each psychologist had a supervisor from the research team who ensured that the interview was performed following the procedures established and who reviewed a random $10 \%$ of the interviews performed.

The project was reviewed and approved by the Sant Joan de Deu and Gol i Gorina Clinical Research Ethics Committees and was authorized by the relevant prison administrations.

For the purpose of this study, the following were considered to be violent offences: homicide and attempted homicide, aggravated assault, common assault, robbery, threatening behavior, harassment, arson and any sexual offence. Burglary, fraud, drug-related offences, financial offences and others were considered non-violent offences.

Inmates with lifetime substance-use disorders were classified by type (alcohol, cocaine, opioids and cannabis) and number of substances consumed.

Computer analysis of responses was performed to detect possible inconsistencies, and a review of questionnaires was performed to evaluate the open questions and notes added by the interviewers. Descriptive univariate analyses were conducted to describe sociodemographic and criminal variables by (or taking into account) type of offence (violent vs. non-violent). A Chi-Square test was performed to establish the association between type of offence and these variables. $A$ binary and multiple logistic regression analyses were fitted to evaluate factors (covariates) associated with violent offences and the odds ratio (CI 95\%) was calculated. We included, in the full logistic regression model, the covariates associated with type of offence in univariate analyses at the 0.05 level of significance. We also fitted an interaction term between offenders and use of substances. All results were significant if $\mathrm{P}<0.05$. To test the validity of model we performed the Hosmer-Lemeshow test. IBM SPSS Statistics 19 was used for statistical analysis.

\section{Results}

Table 1 shows the sociodemographic data, criminal records, and lifetime mental disorder histories grouped according to the presence of violent behavior while committing a crime. The average age was similar for the two groups: 37.4 vs 36.4 years. The inmates who had committed violent crimes were single, separated, or divorced $(\mathrm{p}=0.009)$, with an unemployment rate (34.1\%) prior to incarceration that was significantly higher $(\mathrm{p}=0.003)$. Having been born in Spain was associated with violent crimes $(80.3 \%$ vs $60 \%)$ $(\mathrm{p}=0.0001)$. The level of education attained was the primary, $67.5 \%$ vs $56.3 \%$, for those who had committed violent crimes. 
Table 1. Sociodemographic, criminal and mental health characteristics by type of offence.

\begin{tabular}{|c|c|c|c|c|}
\hline & $\begin{array}{l}\text { Non-violent offences } \\
(\mathrm{n}=270 ; 38 \%)\end{array}$ & $\begin{array}{l}\text { Violent offences } \\
(\mathrm{n}=437 ; 62 \%)\end{array}$ & $\begin{array}{l}\text { Total sample } \\
(\mathrm{n}=707 ; 100 \%)\end{array}$ & $p$-value \\
\hline \multicolumn{5}{|l|}{ SOCIODEMOGRAPHIC CHARACTERISTICS } \\
\hline Age: Mean (SD) & $36.4(9.3)$ & $37.4(10.7)$ & $36.8(9.9)$ & \\
\hline Range (Min - Max) & $20-67$ & $19-67$ & $19-67$ & \\
\hline \multicolumn{5}{|l|}{ Categorized age: $\mathrm{n}(\%)$} \\
\hline From 18 to 28 years & $56 \quad(20.7)$ & $93 \quad(21.3)$ & $149(21.1)$ & 0.316 \\
\hline From 28 to 32 years & $41 \quad(15.2)$ & 64 (14.6) & $105(14.9)$ & \\
\hline From 32 to 36 years & $48 \quad(17.8)$ & $72(16.5)$ & 120 & \\
\hline From 36 to 40 years & 37 (13.7) & $69(15.8)$ & $106 \quad(15)$ & \\
\hline From 40 to 50 years & $51 \quad(18.9)$ & $96(22)$ & $147(20.8)$ & \\
\hline More than 50 years & 34 (12.6) & 33 (7.6) & $67 \quad(9.5)$ & \\
\hline Missing & $3(1.1)$ & $10 \quad(2.3)$ & $13(1.8)$ & \\
\hline \multicolumn{5}{|l|}{ Place of birth: $n(\%)$} \\
\hline Spain & $162(60)$ & $351(80.3)$ & $513(72.5)$ & $<0.0001$ \\
\hline Africa & $40 \quad(14.8)$ & $30(6.9)$ & $70(9.9)$ & \\
\hline America & $42 \quad(15.6)$ & $22(5)$ & $63 \quad(8.9)$ & \\
\hline Asia & $6(2.2)$ & $6(1.4)$ & $12(1.7)$ & \\
\hline Europe & $19(7)$ & $25 \quad(5.7)$ & $44 \quad(6.2)$ & \\
\hline Other & $1(0.4)$ & $3(0.7)$ & $4(0.6)$ & \\
\hline Unknown & - & - & $1 \quad(0.1)$ & \\
\hline \multicolumn{5}{|l|}{ Marital status: $\mathrm{n}(\%)$} \\
\hline Single & $110 \quad(40.7)$ & $201 \quad(46)$ & 311 (44) & 0.009 \\
\hline Married & 101 (37.4) & $115(26.3)$ & $216(30.6)$ & \\
\hline Divorced/separated & $55 \quad(20.4)$ & 105 (24) & $160(22.6)$ & \\
\hline Widowed & 4 (1.5) & $16(3.7)$ & $20(2.8)$ & \\
\hline \multicolumn{5}{|l|}{ Educational level: n (\%) } \\
\hline Illiterate & $3(1.1)$ & $10(2.3)$ & $13(1.8)$ & 0.002 \\
\hline Without studies but can read and write & $11(4.1)$ & $13(3)$ & $24(3.4)$ & \\
\hline Primary education & $152(56.3)$ & $295(67.5)$ & 447 (63.2) & \\
\hline Secondary education & 80 & $106(24.3)$ & $186(26.3)$ & \\
\hline University & $22(8.1)$ & $13(3)$ & $35(5)$ & \\
\hline Other & $2(0.7)$ & $0(0)$ & $2(0.3)$ & \\
\hline \multicolumn{5}{|l|}{ Employment prior to incarceration: $\mathrm{n}(\%)$} \\
\hline Employee & $190(70.4)$ & $251(57.4)$ & $441(62.4)$ & 0.003 \\
\hline Unemployed & $65(24.1)$ & $149(34.1)$ & $214(30.3)$ & \\
\hline Others & $15(5.6)$ & $37(8.5)$ & $52(7.3)$ & \\
\hline \multicolumn{5}{|l|}{ CRIMINAL HISTORY } \\
\hline \multicolumn{5}{|l|}{ Offenders: $\mathrm{n}(\%)$} \\
\hline First time & $156(57.8)$ & $168(38.4)$ & $324(45.8)$ & $<0.0001$ \\
\hline Re-offenders & $114(42.2)$ & $269(61.6)$ & $383(54.2)$ & \\
\hline \multicolumn{5}{|l|}{ Legal situation: $\mathrm{n}(\%)$} \\
\hline Yes & $198(73.3)$ & $381(87.2)$ & $579(81.9)$ & $<0.0001$ \\
\hline No & $68(25.2)$ & $44(10.1)$ & $112(15.8)$ & \\
\hline Missing & $4 \quad(1.5)$ & $12(2.7)$ & $16(2.3)$ & \\
\hline \multicolumn{5}{|l|}{ Criminal record: $\mathrm{n}(\%)$} \\
\hline Prior incarceration & $114(42.2)$ & $269(61.6)$ & $383(54.2)$ & $<0.0001$ \\
\hline Prior trial & 117 (43.3) & $270(61.8)$ & $387(54.7)$ & $<0.0001$ \\
\hline Prior arrest & 119 (44.1) & $298(68.2)$ & 417 (58.9) & $<0.0001$ \\
\hline \multicolumn{5}{|l|}{ MENTAL HEALTH LIFETIME } \\
\hline \multicolumn{5}{|l|}{ Mood disorder: $\mathrm{n}(\%)$} \\
\hline No & $189(70)$ & $228(52.2)$ & $417 \quad(59)$ & $<0.0001$ \\
\hline Yes & 81 & $209(47.8)$ & $290 \quad(41)$ & \\
\hline \multicolumn{5}{|l|}{ Anxiety disorder: n (\%) } \\
\hline No & 174 (64.4) & $213(48.7)$ & $387(54.7)$ & $<0.0001$ \\
\hline Yes & $96 \quad(35.6)$ & $224(51.3)$ & $320(45.3)$ & \\
\hline Psychotic disorder: n (\%) & & & & \\
\hline No & $250 \quad(92.6)$ & $381(87.2)$ & $631(89.3)$ & 0.024 \\
\hline Yes & $20(7.4)$ & $56 \quad(12.8)$ & 76 (10.7) & \\
\hline Adjustment/Somatoform disorder: $\mathrm{n}(\%)$ & & & & \\
\hline No & $247 \quad(91.5)$ & $407(93.1)$ & $654(92.5)$ & 0.417 \\
\hline Yes & $23 \quad(8.5)$ & $30 \quad(6.9)$ & $53 \quad(7.5)$ & \\
\hline Any mental disorder: $\mathrm{n}(\%)$ & & & & \\
\hline No & 131 & $140 \quad(32)$ & $271(38.3)$ & $<0.0001$ \\
\hline Yes & 139 (51.5) & $297 \quad(68)$ & $436(61.7)$ & \\
\hline Use of substances: $n(\%)$ & & & & \\
\hline No substance use & 101 & $67(15.3)$ & $168(23.8)$ & $<0.0001$ \\
\hline Use one substance & $41 \quad(15.2)$ & $74 \quad(16.9)$ & $115(16.3)$ & \\
\hline Use more than one substance & $128 \quad(47.4)$ & $296(67.7)$ & $424 \quad(60)$ & \\
\hline
\end{tabular}


The data concerning the nature of the crimes committed indicated that 437 inmates $(62 \%)$ had been convicted of violent crimes. Of these, the most frequent offence was armed robbery (29.9\%). Murder, homicide and attempted homicide made up $10.1 \%$ of the most serious violent crimes.

In terms of criminal record, there was a notably greater proportion of violent crime among the repeat offenders $(61.6$ vs $42.2 \%$ ). Some $68.2 \%$ had previous arrests in their records and $61.8 \%$ had been tried before.

Of those inmates who had committed violent crimes, $68 \%$ had been diagnosed at some point in their lives with a mental disorder. The most frequently diagnosed of these was anxiety disorder $(51.3 \%)$, followed by mood disorder (47.8\%), psychotic disorder (12.8\%), and somatoform disorders $(6.9 \%)$. Some $84.6 \%$ of inmates convicted of violent crimes showed increased levels of substance abuse; of these, $16.9 \%$ were users of a single substance, mainly alcohol, and $67.7 \%$ used more than one substance.

The relationship among the type of crime, substance use, and the presence of a diagnosis of a mental disorder is examined in Table 2. Only $8.8 \%$ of those with a mental disorder but not using drugs had committed a crime with violence. When the mental disorder is associated with drug use the figure rises to $17.5 \%$. If multiple substances are consumed then the increase reaches $73.7 \%$. And when an inmate used multiple substances, but without there being a diagnosis of a mental disorder, the violent crime level is $55 \%$--clearly greater than the proportion for violent crime $(29.3 \%)$ in the absence of substance use.

Table 2. Relationship between violent offence, drug misuse and mental disorder.

\begin{tabular}{|c|c|c|c|c|c|}
\hline \multirow{4}{*}{ Drug misuse disorder } & \multicolumn{4}{|c|}{ Mental disorder } & \multirow{4}{*}{ Total } \\
\hline & \multicolumn{2}{|c|}{ Present (a) } & \multicolumn{2}{|c|}{ Absent (b) } & \\
\hline & \multicolumn{4}{|c|}{ Type of offence } & \\
\hline & Non-violent & Violent & Non-violent & Violent & \\
\hline No disorder & $70(53.4 \%)$ & $41(29.3 \%)$ & $31(22.3 \%)$ & $26(8.8 \%)$ & $168(24 \%)$ \\
\hline One drug disorder & $18(13.7 \%)$ & $22(15.7 \%)$ & $23(16.5 \%)$ & $52(17.5 \%)$ & $115(16 \%)$ \\
\hline Multiple drug disorder & $43(32.8 \%)$ & $77(55.0 \%)$ & $85(61.2 \%)$ & $219(73.7 \%)$ & $424(60 \%)$ \\
\hline Total & $131(100 \%)$ & $140(100 \%)$ & $139(100 \%)$ & $297(100 \%)$ & 707 \\
\hline
\end{tabular}

a) Significant relationship between offence and misuse. $p$-value $<0.0001$.

b) Significant relationship between offence and misuse. $p$-value $<0.0001$.

Univariate regression analysis indicates that the risk of committing a violent crime is greater, on a statistically significant order, when the inmate:

- is unemployed prior to incarceration

- has no education or only a primary level

- has had a mental disorder throughout his lifetime

- is a repeat offender

- uses one or more substances

With the aim of uncovering the precise relation among the sociodemographic variables, criminal record, type of crime, and likelihood of recidivism in violent crime, we carried out a multivariate regression analysis (Table 3 ).

The risk of committing a violent crime is double for people using a substance compared to those who do not and those who are not repeat offenders $(\mathrm{OR}=2.03 \mathrm{CI} 95 \%$ : 1.08-3.78). This risk increases when considering repeat offenders and those who use more than one substance $(\mathrm{OR}=5.35 \mathrm{CI} 95 \%$ : 1.26-10.05). Table 3 shows that when one takes into account all the possible risk factors associated with violent crime, the presence of a mental disorder turns out not to be significant $(\mathrm{OR}=1.38 \mathrm{CI} 95 \%$ : 0.98-1.95). And the same is true for the interaction between a mental disorder and substance use. 
Table 3. Risk factors associated with violent offence.

\begin{tabular}{|c|c|c|c|}
\hline & OR crude $(95 \% \mathrm{CI})$ & OR adjusted $(95 \% \mathrm{CI})$ & p-value ${ }^{(*)}$ \\
\hline \multicolumn{4}{|l|}{ Employment prior to incarceration } \\
\hline Employee & 1 & 1 & \multirow{2}{*}{0.205} \\
\hline Unemployed/Others & $1.76(1.27-2.43)$ & $1.26(0.88-1.79)$ & \\
\hline \multicolumn{4}{|l|}{ Educational level } \\
\hline $\begin{array}{r}\text { Illiterate/Without studies but can read and write/Primary } \\
\text { education }\end{array}$ & $1.67(1.21-2.31)$ & $1.27(0.9-1.8)$ & \multirow{2}{*}{0.181} \\
\hline Secondary education/University/Other & 1 & 1 & \\
\hline \multicolumn{4}{|l|}{ Any Mental disorder } \\
\hline No & 1 & 1 & \multirow{2}{*}{0.065} \\
\hline Yes & $2(1.46-2.73)$ & $1.38(0.98-1.95)$ & \\
\hline \multicolumn{4}{|l|}{ Offenders } \\
\hline First time & 1 & 1 & \multirow{2}{*}{0.244} \\
\hline Re-offenders & $2.19(1.61-2.98)$ & $0.67(0.34-1.31)$ & \\
\hline \multicolumn{4}{|l|}{ Use of substances } \\
\hline No substance use & 1 & 1 & \\
\hline Use one substance & $2.72(1.67-4.45)$ & $2.02(1.08-3.78)$ & 0.028 \\
\hline Use more than one substance & $3.49(2.40-5.06)$ & $1.35(0.80-2.27)$ & 0.258 \\
\hline \multicolumn{4}{|l|}{ Use of substances*Offender } \\
\hline Use one substance*Re-offender & - & $3.34(1.45-7.7)$ & \\
\hline Use more than one substance*Re-offender & - & $5.35(2.85-10.05)$ & \\
\hline
\end{tabular}

(*) $p$-value for OR adjusted.

OR adjusted for Offenders and Use of substances are at the reference value for the other variables

\section{Discussion}

Violence has a multifactor causality, such that the WHO (24) states that it is an interaction of biological, social, cultural, economic, and political elements that governs the roots of violent behavior. The present study undertook to analyze sociodemographic variables, drug use, the presence of a mental disorder, and a prior record of criminal behavior as factors that may predispose individuals toward violent crime.

Determining which behavior is criminal is not an easy or universal matter. One example of this is the treatment given to those who traffic in drugs under different legislative mandates (25). And as for criminal behavior, it does not necessarily carry a violent component. In our sample $62 \%$ of those surveyed had used violence in committing a crime.

In the profile that emerges from literature, those among the prison population most likely to commit violent crime are young males of low socioeconomic class and with a poor level of education $(13,26-29)$. In our analysis of the sociodemographic variables encompassed by our study, we found that a low educational level, and especially being unemployed prior to incarceration, predisposed subjects to committing violent crimes.

Some have speculated upon the intrinsic violence associated with migration. Our data do not fall in line with this hypothesis, however, as we found that African and South American prisoners tended to commit crimes without recourse to violence. In the literature it will be seen that among immigrant populations, regardless of their place of origin, the most common crimes are robbery and involvement in drug trafficking $(30,31)$, neither of which emerged as typically violent in our study.

Most studies (32-36) establish a greater likelihood of violent behavior among the population with a mental disorder, although it may be inferred that only a sub-group of those with mental disorders exhibit violent behavior (37). People with schizophrenia have been described as being four times more likely to be imprisoned than the general population, although they only represent $5 \%$ of violent crimes (27). In a study by Peterson et al. (38) of 143 delinquents with mental disorders, the frequency and consistency of the symptoms that might induce criminal behavior were examined. Of the 429 violent crimes considered, $4 \%$ were associated with psychosis and $10 \%$ with bipolar disorder, leading to the conclusion that few criminal acts were directly motivated by symptoms of illness. Factors such as substance use, premorbid personality, and social indolence are more relevant and underlie violent behavior in people with mental disorders $(39,40)$.

Thus, while factors such as drug use (41), a history of violent acts, and self-injury associated with a psychiatric diagnosis increase the likelihood of committing violent crimes, no direct or systematic relation can be established criminal behavior and mental disorder $(29,35,41,45)$.

Schizophrenia and other psychoses are associated with 
violence and violent crimes, but the greatest risk seems to arise in comorbid substance abuse. The risk among prisoners with mental disorders and comorbid substance use is similar to that for people without psychosis but abusing substances (46).

In our study the absence of a mental disorder and the consumption of substances $(\mathrm{N}=131)$ in the prison population was related with crimes committed without violence $(\mathrm{N}=70$, $53.4 \%$ vs $\mathrm{N}=41,29.3 \%)$. The high number of users in the population with a mental disorder in our sample $(53 \%$ vs $22.6 \%$ of users without the diagnosis of a mental disorder) indicates the high level of comorbidity that exists. Substance use multiplies the risk of involvement in violent crime, as is shown by the fact that multiple drug use in people with a mental disorder is the most represented among violent crimes. These data are consistent with the findings in the literature, which make it clear that the use of drugs by people with a mental disorder may serve to increase the likelihood of committing violent crimes $(20,47,48)$.

Among the risk factors that emerge for the committing of violent crimes by people with a mental disorder is a criminal record (49). There is some controversy in the literature as to whether people with a mental disorder have a greater tendency to recidivism than those who do not (50). In one meta-analysis, a group of women with psychoses who had committed violent crimes were likelier to do so again in the future compared to the general population, psychotic men, and others with mental disorders. Nevertheless, the same study indicated that there were important differences on this question among different countries (50). In our results the diagnosis of a mental disorder did not constitute a risk factor in the future committing of new violent crimes; the main risk factor involved in criminal recidivism was a prior criminal record. The risk of recidivism is doubled when there is also substance use present, in comparison to inmates without a previous record who do not use substances. In addition, when there was use of more than one substance, the risk found in our study was triple. We feel that these data are relevant to identify predictive risk factors for future violent behavior in a prison population with mental disorders, in particular. This might be explained by the lesser attention paid to this population in the penitentiary environment, and perhaps in particular by the scarcity of healthcare and psychosocial resources needed to guarantee continuity of treatment of these patients once they have left prison.

It was, then, to be expected that the presence of a mental disorder is more closely associated with violent crime when there is substance use, but in our data this finding was not confirmed. Rather, the committing of violent crime was not affected by the presence, or not, of a mental disorder, but it was affected by the fact of substance use.

Our study has a number of limitations. First, it did not include women, people under the age of 18 , those above the age of 75 , and those in preventive care. For this reason the results may not be generalized to these populations. And second, the sample included inmates from the general Spanish penitentiary population while excluding those confined to prison psychiatric units.

In conclusion, our data first and foremost make it clear that in the prison population mental disorders in and of themselves do not carry a greater risk that might explain the committing of violent crime. The risk is increased with substance use, and especially with the use of more than one substance (including alcohol). The likelihood of being involved in new violent crime increases with substance use, which acts as a multiplier, and with a previous criminal record.

From these results one may deduce the importance of identifying the population of substance users in prison from day one. It is essential that there be health and social care policies of prevention and intervention for substance users who are penitentiary inmates. Also clearly needed is a coordinated, multidisciplinary effort involving both prison and community resources to provide treatment both for drug use and mental disorders, to help promote rehabilitation and prevention of violent criminal behavior in this population. Finally, more research is needed concerning mental disorders among the prison population and the risk factors associated with them.

\section{REFERENCES}

[1] Walmsley R. World Prison Population List eleventh edition. Institute for Criminal Policy Research. Birkbeck University of London. London, 2016

[2] InstitutoNacionaldeEstadística.http://www.institucionpeniten ciaria.es/web/portal/documentos/estadisticas.htm. 2016-4-22

[3] Observatorio Europeo de las Drogas y las Toxicomanías (2009), "Informe Anual 2009: El problema de la drogodependencia en Europa" http://www.emcdda.europa.eu /attachements.cfm/att, 2009.

[4] Rafaie R, Olyaee S, \& Sargolzaei A The relationship between the type of crime and drugs in addicted prisoners in Zahedan central prison. International Journal of High Risk Behaviors \& Addiction 2(3):139-140, 2013

[5] Goldstein PJ. The drugs/violence nexus: a tripartite conceptual framework. Journal of Drug Issues 39:143-174, 1985

[6] Bennet T, Holloway K. The association between multiple drug misuse and crime. International Journal of Offender Therapy and Comparative Criminology 49:63-81, 2005

[7] Bennet T, Holloway K and Farrington D. The statistical association between drug misuse and crime: A meta-analysis. Aggression and Violent Behaviour. 13:107-111, 2008.

[8] Fazel S, and Danesh J. Serious mental disorder in 23000 prisoners: a systematic review of 62 surveys. Lancet. 16, 359:545-550, 2002.

[9] Andersen HS Mental health in prison populations. A review with special emphasis on a study of Danish prisoners on remand. Acta Psychiatrica. Scandinavic., 424:5-59, 2004

[10] Vicens E, Tort V, Dueñas RM, Muro A, Pérez-Arnau F, 
Arroyo JM et al. The prevalence of mental disorders in Spanish prisons. Criminal Behavior and Mental Health. 21, 5:321-332, 2011 .

[11] Brugha T, Singleton N, Meztler H, Bebbington P, Farrell M, Jenkins R, Coid J, Fryers T, Metzler D, Lewis G Psychosis in the community and in prisons: A report from the British National Survey of Psychiatric Morbidity. The American Journal of Psychiatry. 162:774-780, 2005.

[12] Brennan PA, Mednick SA, Hodgins S Major mental disorders and criminal violence in a Danish birth cohort. Archives of General Psychiatry. 57, 5:94-500, 2000

[13] Elbogen E.B, Johnson SC. The intricate link between violence and mental disorder: results from the National Epidemiologic Survey on Alcohol and Related Conditions. Archives General of Psychiatry 66, 2:152-161, 2009.

[14] Felthous AR. Schizophrenia and impulsive aggression: a heuristic inquiry with forensic and clinical implications Behavioral Science and Law. 26, 6:735-758, 2008.

[15] Sheldon CT, Aubry TD, Arboleda-Florez J, Wasylenki D, Goering PN. Social disadvantage, mental illness and predictors of legal involvement. International Journal of Law and Psychiatry. 29, 3:249-256, 2006

[16] Villagrá P, Gónzalez, A, Fernández P, Casares MJ., Martín JL, Rodríguez F. Perfil adictivo, delictivo y psicopatológico de una muestra de mujeres en prisión. Adicciones: Revista de Socidrogalcohol. 23, 3:219-226, 2011.

[17] Nederlof AF, Muris P, Hovens JE. The epidemiology of violent behavior in patients with a psychotic disorder: A systematic review of studies since 1980. Aggression and Violent Behavior. 18, 1:183-189, 2013

[18] Sacks S, Cleland C.M, Melnick G, Flyn PM, Knigh K, Friedmann PD, Prendergast M, Coen C Violent offences associated with co-occuring substance use and mental health problems: Evidence from CJDATS. Behavioral Science and Law. 27, 1:51-69, 2009.

[19] SWANZDSAJCS Group. Offenders with mental disorder on five continents: a comparison of approaches to treatment and demographic factors relevant to measurement of outcome. International Journal of Forensic Mental Health. 8,2: 81-96, 2009.

[20] Volavka J. Violence in schizophrenia and bipolar disorder. Psychiatria Danubina 25, 1:24-33, 2013.

[21] Langeveld J , Bjørkly S, Auestad B, Barder H, Evensen J, Ten Velden Hegelstad W, et al. Treatment and violent behavior in persons with first episode psychosis during a 10-year prospective follow-up study. Schizophria Research., $156,2-3: 272-276,2014$

[22] Instituto Nacional de Estadística.http://www.institucionpenit enciaria.es/web/portal/documentos/estadisticas.html?r=m\&a $\mathrm{dm}=$ TES $\& \mathrm{am}=2010 \& \mathrm{~mm}=12 \& \mathrm{tm}=\mathrm{GENE} \& \mathrm{tm} 2=\mathrm{GENE}$. $2016 / 04 / 22$

[23] First, Michael B., Williams, Janet B.W., Spitzer, Robert L., and Gibbon, Miriam: Structured Clinical Interview for DSM-IV-TR Axis I Disorders, Clinical Trials Version (SCID-CT). New York: Biometrics Research, New York State Psychiatric Institute, 2007.

[24] OMS Informe mundial sobre la violencia y la salud.
Organización Panamericana de la Salud. Wahington DC, 2002

[25] Bernal J. Derecho penal comparado. La definición del delito en lo sistemas anglosajones y continental. Ed. Atelier. Barcelona, 2011

[26] Corrigan PW, Watson AC.Findings from the National Comorbidity Survey on the frequency of violent behavior in individuals with psychiatric disroders. Psychiatry Research.136:153-162, 2005

[27] Fazel S, Grann M. The population impact of severe mental illness on violent crime. The American Journal of Psychiatry 163, 8:1397-1403, 2006

[28] Serper MR, Goldberg BR, Herman KG, Richarme D, Dill CA. Predictors of aggression on the psychiatric inpatient service. Comprehensive Psychiatry. 46:121-127, 2005

[29] Swanson JW, Holtzer CE, Ganju VK Violence and the psychiatric disorder in the community. Evidence from the Epidemiologic Catchment Area surveys. Hospital \& Commnunity Psychiatry. 41, 7:761-770, 1990.

[30] Capdevila M, Garreta J. Estrangers a les presons catalanes. Estadística bàsica. Justicia Catalunya $\mathrm{N}^{\circ} 51$. Generalitat de Catalunya, 2011

[31] Morgan C, Burns T, Fitzpatick R, Pinfold V, Priebe S. Social exclusion and mental health: Conceptual and methodological review. The British Journal of Psychiatry. 191: 477-483, 2007

[32] Douglas KS, Guy LS, Hart SD. Psychosis as a risk factor for violence to others: A meta-analysis. Psychological Bulletin. 135, 5:679-706, 2009

[33] Hodgins, S. Violent behavior among people with schizophrenia: A framework for investigations of causes, and effective treatment, and prevention. Philosophical Transactions of the Royal Society of London. 363:2505-2518, 2009.

[34] Link B, Stueve A, Phelan J. Evidence bearing on mental illness as a possible cause of violent behavior. Epidemiology Review. 17 1: 172-181, 1995.

[35] Monahan J. Mental disorder and violent behavior. American Psychologist. 47, 4: 511-521, 1992.

[36] Taylor PJ. Mental disorder and crime. Criminal Behaviour and Mental Health. 14:31-36, 2004

[37] Walsh E, Buchanan A, Fahy T. Violence and schizophrenia: examining the evidence. British Journal of Psychiatry. 180:490-495, 2002.

[38] Peterson JK, Skeem J, Kennealy P, Bray B, Zvonkovic A. How often and how consistently do symptoms directly precede criminal behavior among offenders with mental illness? Law and Human Behavior. 38, 5: 439-449, 2014.

[39] Arsenault L, Moffitt TE, Caspi A. Mental disorders and violence in a total birth cohort. Result from the Dunedin Study. Archives of General Psychiatry. 57: 979-986, 2000.

[40] Monahan J The MacArthur studies of violent risk. Criminal Behaviour and Mental Health. 12: 67-72, 2002.

[41] Fazel S, Wolf A, Palm C, Lichtenstein P. Violent crime, suicide, and premature mortality in patients with 
schizophrenia and related disorders: a 38-year total population study in Sweden. The Lancet Psychiatry, 1, $1: 44-54,2014$

[42] Falk O, Wallinius M, Lundstrom S, Frisell T, Anckarsater H, Kerekes N. The $1 \%$ of the population accountable for $63 \%$ of all violent crime convictions. Social Psychiatry and Psychiatric Epidemiology. 49, 4:559-571, 2013.

[43] Vinkers DJ, Beurs E, Barendregt M, Rinne T, Hoek HW. The relationship between mental disorders and different types of crime. Criminal Behaviour and Mental Health. 21, 5:307-320, 2011.

[44] Hodgins S. The major mental disorders and crime: Stop debating and start treating and preventing. Journal of Law and Psychiatry. 24:427-446, 2001.

[45] Wallace C, Mullen P, Burgess P Criminal offending in schizophrenia over a 25-year period marked by deinstitutionalization and increasing prevalence of comorbid substance use disorders. American Journal of Psychiatry. 161, 4:716-727, 2004.

[46] Fazel S, Gulati G, Linsell L, Geddes JR, Grann, M. Schizophrenia and violence: Systematic review and meta-analysis. Plos One 6, 8:1-15, 2009.

[47] Loinaz I. Psicopatología y delincuencia. En Ortiz-Tallo, M, (Coord), Psicopatología clínica. Adaptado al DSM-5. Pirámide, Madrid. pp. 153-165, 2013.

[48] Chalub M, de Borba Tellez LE. Alcohol, drugs and crime. Revista Brasileira de Psiquiatria. 2:69-73, 2006.

[49] Witt K, Van Dorn R, Fazel S. Risk factors for violence in psychosis: systematic review and meta-regression analysis of 110 studies. Plos One, 8, 2:1-15, 2013.

[50] Fazel S, Yu R. Psychotic disorders and repeat offending: systematic review and meta-analysis. Schizophrenia Bulletin. 37, 4: 800-810, 2009. 